\title{
Merle Calvin Ricklefs (1943-2019), a Note of Appreciation
}

\author{
Michael Laffan \\ Princeton University, Princeton, NJ, USA \\ mlaffan@princeton.edu
}

I first met Merle properly at Mount Beauty, a small town in the Victorian Alps. Of course I knew of Professor Ricklefs from his work on Indonesia, and naturally from his History of modern Indonesia, which remains required reading for any student of that country. I was also well aware of his commanding presence on the campus of the ANU as the director of the then Research School of Pacific and Asian Studies (1993-1998), which I had skirted as I went from being an undergraduate in the Faculty of Asian Studies to an employee at the Menzies Library. And I had also encountered him rather nervously in 1997 at a dinner at the home of Jan Just Witkam, in Leiden, when the latter produced some incredibly old red wine to ensure that his eminent guest would not be afflicted by sulphates. More than this, Professor Ricklefs had been an examiner for my dissertation, and then the more than generous provider of a job reading Dutch microfilm for him in Canberra after his move down to the Melbourne Institute for Asian Languages and Societies. I say more than generous, because he had insisted both that I would spend half my time doing my own work and that I should feel free to use anything that might find. I could not have had a better start.

Truth be told, though, I was still a little terrified of him in 2001. He was known as a hard taskmaster. That initial anxiety only melted in Mount Beauty, when I got my first glimpse of Merle beyond the academy. In preparation for the microfilm job, he had invited my small family to spend the weekend with him and his wife Margaret. We were warmly hosted by them both. And while there was some business to attend to, there was far more time to be spent among the photos of family and friends. Merle's eyes lit up when he spoke of their three children. He also took obvious delight in being up on the mountain, leading us across clear streams and alpine meadows of moss, telling us about the Bogong moths that (once) crammed the nearby caves in winter, before descending each season down towards the Namadgi Valley and the suburbs of Canberra. 
Merle was no moth. Nor was he a butterfly. There was always a certain formality about him, which I had attributed to his time in Leiden and Oxford, but this was only because, growing up in Canberra, I didn't quite know what a Midwesterner was. I am now sorry that I never asked him more about Iowa, or indeed his time at Colorado College, from which he graduated in 1964. He didn't appear such a fan of Cornell, where he had studied with Oliver Wolters. History rather seemed to begin for him in Leiden, where he was in his element between reams of manuscripts and traversing cobbled streets.

In the years to come, I went from a hesitant reader of Dutch reports, worried about the quality of the transcripts I sent him, to an occasional correspondent, if one who still worried about his corrections to what I had written - and they were always deserving corrections! I suspect that many of us came to dread the appreciative note followed by the reams of errata, offered in the spirit that they might be addressed in future editions. Not that many of us have had work reprinted, re-issued, or revised in the way that Merle's was throughout his astonishingly productive career. A careful reader and exacting writer, he was always intent on putting in the maximum of information that could be proven with the strands he had gathered from Javanese, Indonesian, and Dutch writings. He had little time for accounts that did not adhere as closely to the sources, and he seemed in some ways to be a polished representative of the best of the Dutch tradition. No wonder, too, that he became one of a handful of scholars to have been made an honorary life member of the KITLV.

He also had a humorous side to pair with his precision. A lover of anecdotes about colleagues and friends, he once grinned while recounting how, on informing the late G.W.J. Drewes at Noordhoek that he had lunched with C.C. Berg, the former had drawn himself up and informed him that he should be aware that Berg was his 'enemy'. Yet there was also care and gratitude for the many scholars who had directed his path, including H.J. De Graaf and Theodore G.Th. Pigeaud, whose curious text on the Malay annals of Semarang and Cirebon he edited in 1984 while serving as professor of history at Monash University.

Merle was certainly curious about China, but, once awakened, his scholarly passion was ever for the courtly culture of Java, with its deep literary tradition and, never to be forgotten, its crucial role in shaping understandings of Islam on the island and across the archipelago. While perhaps best known for his works on the eighteenth century, including his final, solo-authored book, a fine biography of Prince Mangkunagara (1726-1795), Merle once told me that he had originally decided to go back into the deeper past in order to write an authoritative account of change in the nineteenth century, which he did indeed do with his magisterial Mystic synthesis in Java of 2006 and then his Polarising Javanese 
society of 2007. In a sense, too, this quest was animated by a desire to explain the myth of an eternally divided Java, commonly siloed into Geertz's notions of abangan, santri, and priyayi.

Merle valued synthesis over singularity — as long as the components were of the highest quality. His passions often encompassed realms that I was yet to appreciate. An avid fan of jazz, and indeed live music, his enthusiasm was of such a commanding nature that I dared not say that it was not quite for me when he launched himself at the CD player at Mount Beauty, or when he hosted me in Singapore when he was still serving as a professor at the National University of Singapore. Ever neat, too, after an evening of Thai food and (yes) jazz at Boat Quay, I remember him laying out breakfast with fastidious attention, before heading out on his customary walk. Singapore suited him, too, it seemed.

Never one to be beaten back, or down, Merle had a disarming frankness. But there was also a genuine care for others. He was rightly recognized for his commitment to educational opportunities for indigenous students in Australia, a country he loved despite its maddening political culture. Merle was also unafraid of speaking out against jingoistic consensus, as when a colleague in Melbourne called for a decrease in Asian immigration to a nation that had only recently forsworn its embarrassing past of racial exclusion. Some habits die hard.

That combination of frankness and care was also shaped by family tragedy that readily transformed into personal sympathy, and an appreciation for his own mortality. Where chronic illness might have stopped a more timid scholar, Merle pushed himself to the limit of what he could and very much wanted to do. Our last meetings were chance encounters in Canberra, or rather tales of near-misses in the Asia Bookroom, whose shelves now bear the weight and the warmth of a scholar who wants his knowledge to be passed on to future generations. He will be missed just as he will long continue to be read.

\section{Major Publications, Many Subsequently Reprinted and Translated}

\section{Authored Works}

Jogjakarta under Sultan Mangkubumi, 1749-1792: A history of the division ofJava. London: Oxford University Press, 1974.

with P. Voorhoeve, Indonesian manuscripts in Great Britain: A catalogue of manuscripts in Indonesian languages in British public collections. London Oriental Bibliographies. Vol. 5. New York: Oxford University Press, 1977.

Modern Javanese historical tradition: A study of an original Kartasura chronicle and related materials. London: School of Oriental and African Studies, 1978. 
A history of modern Indonesia, ca. 1300 to the present. London: Macmillan, 1981.

Islam in the Indonesian social context. Clayton: Centre of Southeast Asian Studies, Monash University, 1991. [Annual Indonesian Lecture Series 15.]

War, culture and economy in Java, 1677-1726: Asian and European imperialism in the early Kartasura period. St. Leonards: Allen \& Unwin, 1993.

The seen and unseen worlds in Java, 1726-49: History, literature and Islam in the court of Pakubuwana II. St. Leonards: Allen \& Unwin, 1997.

Mystic synthesis in Java: A history of Islamization from the fourteenth to the early nineteenth centuries. White Plains, NY: Eastbridge, 2006.

Polarising Javanese society: Islamic and other visions c. 1830-1930. Honolulu: University of Hawai'i Press, 2007.

Islamisation and its opponents in Java: A political, social, cultural and religious history, c. 1930 to the present. Singapore: National University of Singapore Press, 2012.

Soul catcher: Java's fiery Prince Mangkunagara I, 1726-1795. Copenhagen: Nordic Institute of Asian Studies, 2018.

\section{Edited Works}

with Andrew Markus. Surrender Australia? Essays in the study and uses of history: Geoffrey Blainey and Asian immigration. Sydney etc.: Allen \& Unwin, 1985.

with David P. Chandler. Nineteenth and twentieth century Indonesia: Essays in honour of Professor J.D. Legge. Clayton: Centre of Southeast Asian Studies, Monash University, 1986. [Monash Papers on Southeast Asia 14.]

with Bruce Lockhart, Albert Lau, Portia Reyes and Maitrii Aung-Thwin. A new history of Southeast Asia. Basingstoke: Palgrave Macmillan, 2010. 


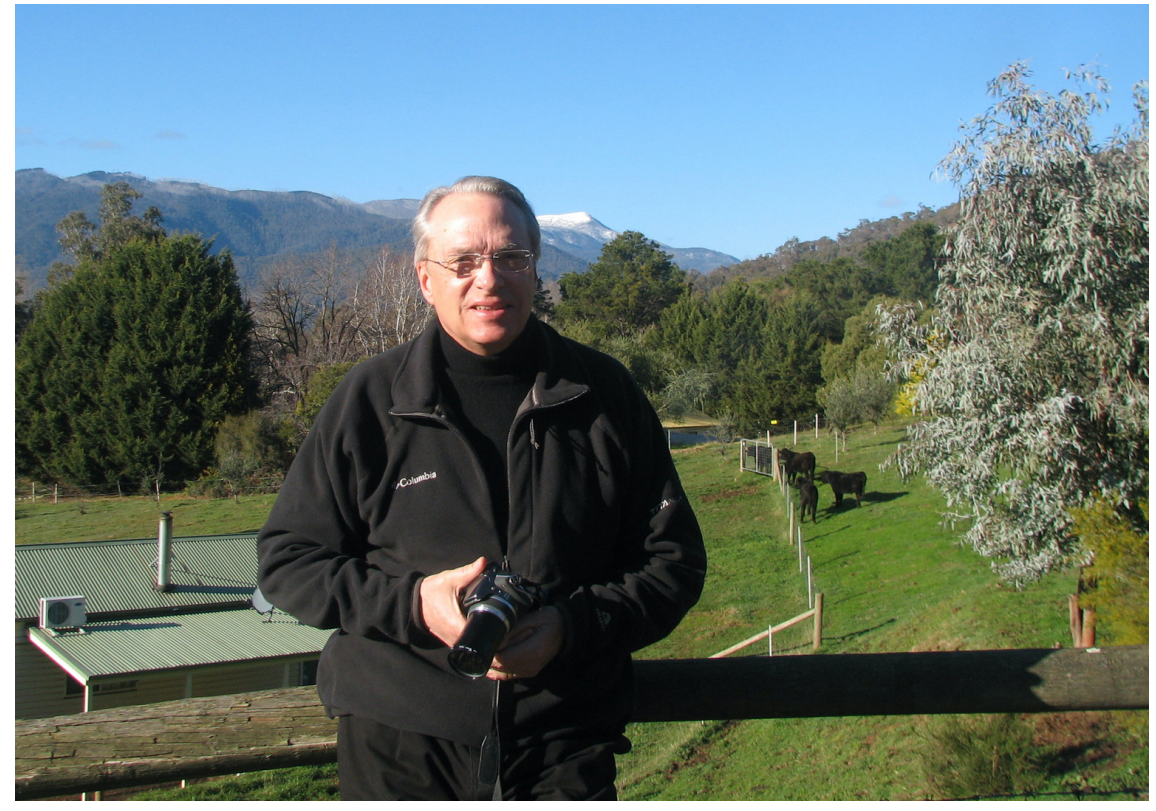

Merle Calvin Ricklefs 